\title{
Hidden potential of fruit waste and its utilization
}

\section{Potencial oculto de los residuos de frutas y su utilización}

\author{
Damini Soni ${ }^{1}$ and Gargi Saxena ${ }^{2}$ \\ 1- Research Scholar, IIS(Deemed to be University), Department of Home Science, Jaipur, \\ India. E-mail:daminisoni1013@gmail.com
}

2- Senior Assistant Professor, IIS(Deemed to be University), Department of Home Science, Jaipur, India

\begin{abstract}
The global increasing population demands for more food production and food processing which consequently results in more food waste generation. The total waste produced in different stages of processing of food generally comprises of peels, pomace, seed, pulp, unused flesh and damaged food which is biodegradable in nature. These by-products are a good source of bioactive compounds like polyphenols, antioxidants and phytochemicals. They are the storehouse of complex carbohydrates, lipids, proteins and nutraceuticals depending on the nature of product produced for example poultry and meat industries are rich the source of proteins and lipids, fruits and vegetable processing industries are rich in bioactive compounds and cereal industries are good source of phenolic compounds and dietary fiber. The food waste or by-products are important source of colorants, fiber, flavoring and antimicrobials which are used in food industry as a source of food additives. The phenolic compounds present in by products of different foods exhibit anti-oxidant, anti-microbial, anti-inflammatory, immunemodulatory activity and play a major role in reducing the risk of cardiovascular problems, osteoporosis, thrombosis, platelets aggregation and diabetes in humans. By products from different industries can be used to develop value added products in India where poverty and malnutrition are the major issues. Developing effective policies for the utilization of food waste along the value chain can help reduce food waste problem and contribute towards food security and sustainability.
\end{abstract}

Keywords: By products, Bioactive compounds, Food industry, Food waste.

\section{RESUMEN}

La creciente población mundial exige una mayor producción y procesamiento de alimentos, lo que en consecuencia da como resultado una mayor generación de desperdicio de alimentos. Los residuos totales producidos en las diferentes etapas del procesamiento de los alimentos generalmente se componen de cáscaras, orujos, semillas, pulpa, pulpa no utilizada y alimentos dañados que son de naturaleza biodegradable. Estos subproductos son una buena fuente de compuestos bioactivos como polifenoles, antioxidantes y fitoquímicos. Son el almacén de carbohidratos complejos, lípidos, proteínas y nutracéuticos dependiendo de la naturaleza del producto producido, por ejemplo, las industrias avícola y cárnica son ricas, la fuente de proteínas y lípidos, las industrias de procesamiento de frutas y verduras son ricas en 
compuestos bioactivos y las industrias de cereales son buenas fuente de compuestos fenólicos y fibra dietética. Los residuos o subproductos alimentarios son una fuente importante de colorantes, fibras, aromatizantes y antimicrobianos que se utilizan en la industria alimentaria como fuente de aditivos alimentarios. Los compuestos fenólicos presentes en los subproductos de diferentes alimentos exhiben actividad antioxidante, antimicrobiana, antiinflamatoria, inmunomoduladora y juegan un papel importante en la reducción del riesgo de problemas cardiovasculares, osteoporosis, trombosis, agregación plaquetaria y diabetes en humanos. . Los subproductos de diferentes industrias se pueden utilizar para desarrollar productos de valor agregado en la India, donde la pobreza y la desnutrición son los principales problemas. El desarrollo de políticas eficaces para la utilización del desperdicio de alimentos a lo largo de la cadena de valor puede ayudar a reducir el problema del desperdicio de alimentos y contribuir a la seguridad alimentaria y la sostenibilidad.

Palabras clave: Subproductos, Compuestos bioactivos, Industria alimentaria, Residuos alimentarios.

\section{INTRODUCTION}

Due to an increase in the world population, economic development and income growth the demand for production and processing of food is also increasing. Hence food industries are growing in huge number to provide a wider range of food products to satisfy the needs of the consumers resulting in increased amount of food waste and their by-products (Kearney, 2010). The major food industries in the world include dairy, meat, poultry, cereal and seafood which generate a large amount of waste and by products consisting of high amount of organic matter resulting into problems regarding disposal, environmental pollution and sustainability (Russ, 2004). According to FAO statistics, 1.3 billion tons of food is lost or wasted globally where the waste is estimated to be $30 \%$ of cereals, $40-50 \%$ for roots crops, fruits and vegetables, $20 \%$ for oilseeds and $30 \%$ for fish (FAO, 2012) while on the other hand, 842 million people in poor countries are experiencing chronic hunger (FAO, 2013). In India, approximately 1.81 million tonnes of fruit and vegetable waste is generated which can be used to produce value added products to combat hunger and malnutrition. Food waste is the rich source of various components such as protein, carbohydrate hemicelluloses, cellulose, starch, and sugars like sucrose, fructose, and glucose], oil, mineral, polyphenols, phytochemicals, and fat (Pham, 2015). Waste valorization is a new concept that offers a wide range of alternatives for the management of waste other then disposal and land filling.

\section{BY-PRODUCTS OF FOOD PROCESSING IN INDIA}

Apple pomace: Apple is the oldest and important fruit crop to mankind with an annual production of 1.98 million tonnes from an area of 0.27 million hectares (FAO, 2010). In India, $60 \%$ of the apples come from Kashmir, 30\% from Himachal Pradesh and $10 \%$ from Uttarakhand (NHB, 2010). Apple pomace is by product of apple which contains peels, seeds, remaining solid parts rich in simple carbohydrates, acids, vitamin c, minerals, fiber and antioxidants (Sun et al.,2007). They are good source of polyphenols, which are mainly present in the peels such as catechin, quercetin, hydroxyl cinnamates, chlorogenic acid, and epicatechins (Mamma et al.,2009). Apple pomace contains 10-15\% pectin (Wang and Lai, 2016) 35-60\% non-starch polysaccharides, $36.5 \%$ insoluble fiber, $14.6 \%$ soluble fiber (Sudha et al.,2007). 
According to research done on fisher rats apple pomace have resulted to improve gut health (Ravn et al.,2018). Apple extracts helps in improving lipid metabolism, antioxidant status and gastrointestinal function with a positive effect on metabolic disorders like hyperglycemia and insulin resistance (Skinner et al.,2018). Apple pomace being the richest source of phenolic compound display health promoting activities based on antioxidant, anti-inflammatory and anti-microbial properties inhibiting the fat production of sebaceous cells making them appropriate to be used as anti-acne cosmetic formulation (Alvarez et al.,2018). In a recent research apple pomace was used to enrich short dough biscuits replacing wheat flour to reduce their glycemic index, thus satisfying the need to manage type 2-diabetes and to valorize food by products (Alongi et al.,2019). According to research done by (McCann et al., 2007), the crude extracts from apple pomace help prevent colon cancer in vitro.

Banana peel: Banana is the largest growing tropical fruit with $16 \%$ of total fruit production worldwide and India is the largest producer of banana with $27 \%$ of world's banana production (Mohapatra et al.,2010). Global production of Banana was found to be 117 million tons in 2017 and India produced 29 million tonnes per year on an average between 2010 and 2017 (FAO, 2017). Banana fruit is mainly consumed which is protected by its peel. $30 \%$ of banana fruit is its peel which is a by-product and is generally discarded (Ibrahim et al.,2017). Banana peel contains moisture [79.2], protein [0.83], fat [0.78], minerals [2.11], carbohydrates [5] and fiber [1.72] per 100gms (Mani and Sethi, 2000). They are rich in lipids [2.2-10.9\%] which are polyunsaturated fatty acids mainly linoleic and a-linolenic acids and have their activity in prevention of atherosclerosis, cancer, heart disease and diabetes (Emaga et al.,2007).

Peels comprised of $8 \%$ crude fiber, $6.2 \%$ ether extract, $13.8 \%$ soluble sugars and $4.8 \%$ total phenolic compounds (Kanazawa, 2000). Banana peels have significant nutritional qualities and are good source of starch [3\%], crude fat [6\%], total dietary fiber [11\%] (Mohapatra, 2010) lignin [6-12\%], pectin [10-21\%], cellulose [7.6-9.6\%], hemicelluloses [6.4-9.4\%] and also contain glucose, galactose, arabinose, xylose [21\%]. The peel is abundant source of phytochemical compounds likegallocatechin [160mg/100g dry wt], anthocyanin, delphinidin, cyanidin, caretenoids, xanthophylls, catecholamines, sterols and triterpenes (Kanazawa, 2000). The presence of terpenoid and flavanoids in banana peel exhibits anthelmintic properties (Marie et al.,2010).

Banana peel powder is used to develop biscuits providing low calories and high fiber (Joshi, 2007). The peel shows anti-microbial properties towards pathogenic fungi as they are used to generate silver nano particles being rich source of polymers like hemicelluloses, lignin and pectin (Bankar, 2010). Banana peels are also used as a base material for pectin extraction, as a substrate for biogas production, source of alkali in soap production (Udosen, 2000), etanol extraction (Tiwari, 1986) and wine production (Faturoti, 2006).

Since Banana peel is highly rich in bioactive compounds including dietary fiber it is a great source for the production of valuable, functional new food products at low cost.

Watermelon rinds: Watermelon is a fruit grown in warmer regions of the world and its biomass is categorized into $68 \%$ flesh, $2 \%$ seeds and $30 \%$ rind of the total weight (Kumar, 2015)(Anonymous, 2015). Watermelon rinds are usually discarded as waste but it is edible and can be used as vegetable due to its good nutritional value. It contains $10.61 \%$ moisture, $13.09 \%$ ash, $2.44 \%$ fat, $11.17 \%$ protein and $56.00 \%$ carbohydrates (Sayed, 2013) and is a good source of anti-oxidants, flavanoids and lycopene. The rinds are rich in B vitamins specially 
B1 and B6 (Naz et al.,2014). Watermelon rind is used in making candies, pickles, cheese and vadiyam (Simonne, 2002) (Madhuri, 2003). An important compound present in rind is citrulline which is converted to arginine, helpful in maintaining cardiovascular, immune and circulatory system. Citrulline gives anti-oxidant effect which helps in preventing body from free radical damage. According to a research, rinds help in preventing cancer and circulation problems by relaxing blood vessels (Rimando, 2005). Watermelon rinds have shown to improve hypercholesterolemia in rats when they were fed with high cholesterol diet together with improvement in hepatic tissue structure (Hiamed, 2018). Watermelon peel is used for the production of single cell protein as a sole source carbon in preparation of fermentation media on which strains of yeast S.cerevisiae have been used (Wadhwa et al.,2015). In China the dried powder of the rinds are used for curing aphthous mouth sores (Rahman, 2013). Hence watermelon waste is found to be a rich source of nutrients which are incorporated in cakes, flours, candies, Jams, steamed cupcakes, pan bread and can further be used for making different value added products so that the waste or by products of watermelon can be utilized efficiently.

Mango peel and kernels: Mango is a seasonal fruit produced in India known to be king of all tropical fruits; its $20 \%$ is processed for production of food products such as puree, pickle, nector, leather, slices juices and chutney (Ravani, 2013). Production of mango in India is 15.19 million tonnes annually [4]. Mango waste mostly includes $7-24 \%$ peels, $13.5 \%$ of seeds, 9 $40 \%$ kernels and $18 \%$ of unusable pulp (Sagar et al., 2018). Mango peel is a major by product of mango which is currently not utilized and is discarded leading to pollution. Mango peels are good source of valuable bioactive compounds like polyphenols, carotenoids, vitamin E, dietary fiber and vitamin C (Ajila, 2007). Mango seed kernel and peels have also shown the presence of phytoesterols including campesterol, bsitosterol, stigmasterol, tocopherols and some phenolic compounds including tannins, gallic acid, coumarins, ellagic acid, vanillin, magniferon, ferulic acid and cinnamic acid (Ashoush, 2011). Mango by products have shown to possess good amount of dietary fiber where peel contains $51.2 \%$ Total dietary fiber [ $32 \%$ insoluble and $19 \%$ soluble fiber] with galactose, glucose and arabinose as major neutral sugars where as mango kernel contains $2 \%$ crude fiber only (Sagar et al.,2018). The carotenoids content of mango waste is found to be good which play very important role in human health by acting as biological antioxidant and protecting cells and tissues from toxic effect of free radicals (Wadhwa et al.,2015).

The seed kernel and peel are also used in pharmaceutical industries as they contain gallate and penta-O-Galloyl-glucoside which exhibits anti-tumor, anti-oxidant, anticardiovascular, hepato-protective, anti-fungal and anti-microbial effects (Wadwa et al.,2015). . The seed kernel contains low amount of protein but is good source of essential amino acids including leucine, valine and lysine (Ravani, 2013). The pectin present in mango peel exhibits good gelling capacity than other citrus pectins. The flour developed from mango peel and kernel is used for developing healthy food as a source of functional ingredients in noodles, breads, biscuits, sponge cakes, yoghurt, Jams, vinegar and other bakery products (Wadhwa et al.,2015).. Mango peel nowadays is been used for the production of lactic acids and single cell proteins using Pichia pinus yeast.

Table 1 Nutritive value and production of fruit waste. 
Sustainability, Agri, Food and Environmental Research, (ISSN: 0719-3726), 9(3), 2021: 469-479 http://dx.doi.org/10.7770/safer-VONO-art2213

\begin{tabular}{|c|c|c|c|c|c|}
\hline Fruit Name & By products & $\begin{array}{l}\text { Waste } \\
\text { produced }\end{array}$ & References & $\begin{array}{l}\text { Composition(g/100g) } \\
\text { Elements(mg/100g) }\end{array}$ & References \\
\hline Apple & Pomace & & & $\begin{array}{l}\text { Protein (2.8), } \\
\text { Carbohydrates(59.96) } \\
\text { Fat(9.9), Fiber(13.95) } \\
\text { Ash(1.39), Calcium(14.89) } \\
\text { Zinc(0.95), Iron (25.63) } \\
\text { Manganese(1.28) }\end{array}$ & (Romelle et al., 2016) \\
\hline Banana & Banana peel & $35 \%$ & (Gupta, 2000) & $\begin{array}{l}\text { Protein(10.44), } \\
\text { Carbohydrates(43.40) } \\
\text { Fat(8.40), Fiber(11.81) } \\
\text { Ash(12.45), Calcium(19.86), } \\
\text { Zinc(1.72) } \\
\text { Iron(15.15), Manganese(9.05) }\end{array}$ & \\
\hline Watermelon & Peel & & & $\begin{array}{l}\text { Protein(6.44),Carbohydrates(3 } \\
\text { 2.16) Fat(12.61), } \\
\text { Fiber(26.31), Ash(5.03) } \\
\text { Calcium(11.21), Zinc(3.78) } \\
\text { Iron(45.58), Manganese(1.25) }\end{array}$ & \\
\hline Mango & Peel & $45 \%$ & (Sagar et al.,2018) & $\begin{array}{l}\text { Protein(5),Carbohydrates(63.8 } \\
0) \\
\text { Fat(4.72), } \\
\text { Ash(3.24) } \\
\text { Calcium(60.63), Zinc(0.66) } \\
\text { Iron(15.43), } \\
\text { (12.79), Manganese(4.77) }\end{array}$ & $x^{2}$ \\
\hline & Kernel & & & $\begin{array}{l}\text { Protein(6.36), } \\
\text { Carbohydrates(32.2) } \\
\text { Fat(13), Fiber(2.02) }\end{array}$ & (Kittiphoom, 2002) \\
\hline Peas & Pea pods & $40 \%$ & (Gupta, 2002) & 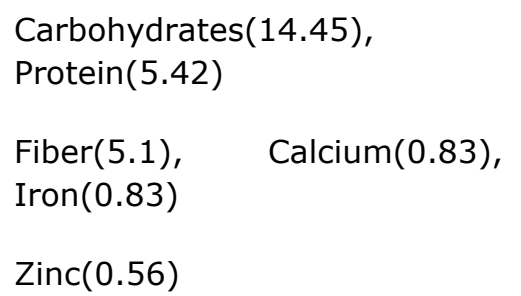 & (Kumar,2015; Garg,2015) \\
\hline
\end{tabular}

Table 2 Bioactive compounds present in different fruit by products. 
Sustainability, Agri, Food and Environmental Research, (ISSN: 0719-3726), 9(3), 2021: 469-479 http://dx.doi.org/10.7770/safer-VON0-art2213

\begin{tabular}{llll}
\hline Fruit & Waste part & Bioactive compounds & References \\
\hline Apple & Pomace & $\begin{array}{l}\text { Hydroxycinnamates, phloretin } \\
\text { glycosides, quercetin, glycosides, } \\
\text { catechins, procyanidins }\end{array}$ & (Sagar et al.,2018) \\
Banana & Peel & $\begin{array}{l}\text { Carotenoids (palmitate or caprate, } \\
\text { xanthophylls, }\end{array}$ & \\
Watermelon & Rinds & laurate) & \\
Mango & Peel and kernel & $\begin{array}{l}\text { Tannin, Gallic acid, Coumarin, Caffic } \\
\text { acid }\end{array}$ & (Ravani, 2013) \\
& & Vanillin, Mangiferin, Ferulic acid & \\
Peas & Cinammic acid & \\
& & Kaempeferol, Querecetin, Myricetin & (Verma, 2012) \\
\hline
\end{tabular}

Pea pods: India is the second largest producer of peas [17.41 million metric tons/annum] after China contributing to $22.9 \%$ of the total world production (Wadhwa et al.,2017). 30\% of the total pea weight is owing to pea pods and more than 1 million tons of pea pods are wasted annually in India. Pea peel or pod is the main by product of peas which are highly nutritious containing $12-15 \%$ dry matter, $18.5-20 \%$ crude protein, $48-57 \%$ neutral detergent fiber, $43-52 \%$ neutral detergent solubles, $24-26 \%$ cellulose and $3.9-4.0 \%$ acid detergent lignin (Wadhwa et al.,2006).

Pods are good source of fiber containing 58.6\%-82.3\% total dietary fiber including soluble fiber [4.2\%] and Insoluble fiber [54.4\%] (Sharma et al.,2016). In a study the pods are studied for its bioactive compounds which represents that the pea pods are source of flavanoids, anti-oxidants, phenols and exhibited in vitro alpha amylase activity. Also ethyl acetate extract showed an anti-bacterial and anti-fungal activity (Hadrich et al.,2014). The pea peel waste contains $90.33 \%$ total sugar, $32.36 \%$ glucose, $18.85 \%$ xylose, $61.35 \% \mathrm{~h}$ holocellulose, $6.9 \%$ lignin, $4.8 \%$ ash, $1.34 \%$ total fat, $13.2 \%$ total protein and $3.53 \%$ moisture (Rehman et al.,2015).

The peel which is nutrient rich is a waste which is now a days been used in developing biscuits, bakery products and for production of bio-ethanol. It is a lignocellulosic by-product which is used as a material for cellulose production (Gupta, 2016).

Orange peel: Orange constitutes around $60 \%$ of the total citrus world production where the world production of citrus was 122 million tons in 2008 (Hegazy, 2012). Orange is mainly used by juice producing industries where the peel is generally wasted. Orange peel is storehouse of anti-oxidants which help reduce oxidative damage and fight free radicals. It also contains histamine suppressing compounds which performs irritation reducing activity and providing support against problematic respiratory indications (Chatterjee, 2014).Vitamin C present in peel helps in boosting immune system. Peel comprise of cellulose, hemicelluloses, lignin, pectin [galacturonic acid], chlorophyll and limonene (Pathak et al.,2017). The peel has 
been reported to exhibit anti-carcinogenic, germicidal and anti-oxidant properties thus effective against skin inflammation, breast cancer, muscle pain, ringworm, colon cancer (Khaskheli et al.,2011). The peel contains total sugars [9.21 to $23.8 \%$ ], Carbohydrates [40.47 to $42.90 \%$, Protein [0.5\% to $8.72 \%$ ], total ash [1.50 to $14.35 \%$ ], Cellulose [2 to $13.61 \%$ ], Moisture [2.20 to $11.86 \%$, Fat [1.57 to $10.00 \%$ ] and Total dietary fiber [12.47 to $74.87 \%$ ] (Gupta, 2016). The nutritional value of the peel is high hence it is used in making vinegar through fermentation. Orange peel oil is also been developed which is used in treating prolapsed of uterus and rectum, diarrhea and piles (Wadhwa et al.,2015) . The peels been low cost are used as absorbents for removing dyes from waste water also its been used for producing single cell protein through fermentation (Wang et al.,2007). Orange peel is used to develop various products like in pureed form it is added to smoothies, used in making biscuits, and being rich in fiber and flavanoids namely tangeretin and nobiletin are good for fighting skin cancer (Chatterjee, 2014). The peel in future researches can be used in powdered form to be incorporated in various food products for value addition like in making jams, cookies, beverages etc.

\section{OTHER BY-PRODUCTS}

Food processing waste and by products are generated during processing of various food products which are been discarded and are not used beside their good nutritional value. Different types of waste from industries include waste from cereal products like husks, hull, rice bran; From fruits and vegetable processing like peel, pomace, seeds, pulp, stem, fiber, skin; from poultry processing like skin, bones, blood, feather, liver, intestines; from marine products processing like viscera, heads, backbones, blood, shells; from dairy processing like whey and lactose (Ezejiofer et al., 2011). These waste products now a days are been used to develop value added products and are also been used in bioethanol production, generation of single cell proteins, in nutraceuticals industries, in development of bio-pigments and colorants, edible oils, emulsifiers, fermented edible products, organic acids and minerals, production of enzymes, biodegradable plastic, biofuel, fertilizers, preservatives and bio-pesticides. Advancements in the food industries are resulting into development of value added products from food processing waste and by products which will help in reduction of pollution and utilization of waste products for generation of low cost food products which can be used for eradicating hunger and malnutrition in poor strata of the societies around the world.

\section{DECLARATION OF CONFLICTING INTERESTS}

The author(s) declared no potential conflicts of interest with respect to the review, authorship, and/or publication of this article.

\section{REFERENCES}

Abu-Hiamed $\mathrm{H}$. Hypocholesterolemic effects of watermelon fruit rind on rats. Nutrition \& Food Science. 2018;48(5):836-45.

Alongi M, Melchior S, Anese M. Reducing the glycemic index of short dough biscuits by using apple pomace as a functional ingredient. LWT. 2019;100:300-5.

AlvarezArraibi A, Barreira J, Barros L, Dias MI, Mandim F, Ferreira IC. Apple pomace as a source of phenolic compounds with potential application in cosmetic product. XXIV EncontroLuso Galego de Química. 2018. 
Al-Sayed HM, Ahmed AR. Utilization of watermelon rinds and sharlyn melon peels as a natural source of dietary fiber and antioxidants in cake. Annals of Agricultural Sciences. 2013;58(1):83-95.

Ajila CM, Bhat SG, Rao UP. Valuable components of raw and ripe peels from two Indian mango varieties. Food Chemistry. 2007;102(4):1006-11.

Anonymous. Food service-watermelon basics.2014: http://www.watermelon.org /FoodService/Watermelon-Basics.aspx. Accessed on 23 January 2015.

Ashoush IS, Gadallah MG. Utilization of mango peels and seed kernels powders as sources of phytochemicals in biscuit. World Journal of Dairy and Food Science. 2011;6(1):35-42.

Bankar A, Joshi B, Kumar AR, Zinjarde S. Banana peel extract mediated novel route for the synthesis of silver nanoparticles. Colloids and Surfaces A: Physicochemical and Engineering Aspects. 2010; 368(1-3):58-63.

Chatterjee S. Therapeutic fruit peels: Their role in preventing lifestyle disorders. Recent Research in Science and Technology. 2014;6(1).

Emaga $\mathrm{TH}$, Andrianaivo RH, Wathelet $\mathrm{B}$, Tchango JT, Paquot $\mathrm{M}$. Effects of the stage of maturation and varieties on the chemical composition of banana and plantain peels. Food Chemistry. 2007;103:590-600.

Ezejiofor TI, Enebaku UE, Ogueke C. Waste to wealth-value recovery from agro-food processing wastes using biotechnology: a review. British Biotechnology Journal. 2014;4(4):418-81.

FAO. 2010. Production Year Book. Food and Agriculture Organization, Rome.

FAO, 2012. Towards the Future We Want: End Hunger and Make the Transition to Sustainable Agricultural and Food Systems. Food Agriculture Organization of the United Nations, Rome.Food and Agriculture Organisation of the United Nations (FAO), International Fund for Agricultural Development (IFAD), United Nations World Food Programme (WFP) (2013). The State of Food Insecurity in the World 2013. The multiple dimensions of food security. FAO: Rome (Italy).

FAO, I. F. A. D, UNICEF. (2017). WFP, WHO (2017). The state of food security and nutrition in the world 2017. Building Resilience for Peace and Food Security (Food and Agriculture Organization, Rome).

Faturoti BO, Emah GN, Isife BI, Tenkouano A, Lemchi J. Prospects and determinants of adoption of IITA plantain and banana based technologies in three Niger Delta States of Nigeria. African Journal of Biotechnology. 2006;5(14).

Garg M. Nutritional Evaluation and Utilization of Pea Pod Powder for Preparation of Jaggery Biscuits. Journal of Food Processing \& Technology. 2015;6(12):1.

Gupta K. Fermentative utilization of waste from food processing industry. In: Postharvest Technology of Fruits and Vegetables: Handling Processing Fermentation and Waste Mangement, Vol. 2 Verma LR and Joshi VK. Indus Pub Co, New Delhi. 2000.

Gupta U. C. Phytochemical analysis and antioxidant acidity of plant waste materials and their transformation into value added products.2016

Hadrich F, El Arbi M, Boukhris M, Sayadi S, Cherif S. Valorization of the peel of pea: Pisum sativum by evaluation of its antioxidant and antimicrobial activities. Journal of oleo science. 2014;63(11):1177-83.

Hegazy AE, Ibrahium MI. Antioxidant activities of orange peel extracts. World Applied Sciences Journal. 2012;18(5):684-8.

Ibrahim UK, Kamarrudin N, Suzihaque MU, Hashib SA. Local Fruit Wastes as a Potential Source of Natural Antioxidant: An Overview. In IOP Conference Series: Materials Science and Engineering. 2017; 206(1): 012040. 
Joshi RV. Low calorie biscuits from banana peel pulp. Journal of Solid Waste Technology and Management. 2007; 33(3):142-147.

Kanazawa K, Sakakibara H. High content of dopamine, a strong antioxidant, in Cavendish banana. Journal of Agriculture and Food Chemistry. 2000; 48(3):844-848.

Khaskheli MI, Memon SQ, Siyal AN, Khuhawar MY. Use of orange peel waste for arsenic remediation of drinking water. Waste and Biomass Valorization. 2011;2(4):423.

Kearney J. Food consumption trends and drivers. Philosophical Transactions of the Royal Society B. 2010; 365:2793-807.

Kittiphoom S. Utilization of mango seed. International Food Research Journal (Malaysia).2002; $19(4), 1325-1335$.

Kumar N. Green pea pods spoilage due to Fusarium oxysporumSchltdl. at Panchgaon, Gurgaon, Haryana, India. International Journal of Current Microbiology and Applied Sciences.2015: 4(7), 426-431.

Madhuri P, Devi K. Value addition to watermelon fruit waste. Journal of food science and technology. 2003;40(2):222-4.

Marie-Magdeleine C, Boval M, Philibert L, Borde A, Archime` de H. Effect of banana foliage (Musa paradisiaca) on nutrition, parasite infection and growth of lambs. Livestock Science2010;131:234-9.

Mamma D, Topakas E, Vafiadi C, Christakopoulos P. Biotechnological potential of fruit processing industry residues. In Biotechnology for agro-industrial residues utilization. Springer, Dordrecht. 2009; 273-291.

Mani SB, Sethi V. Utilization of fruits and vegetables processing waste In. Postharvest Technology of Fruits and Vegetables: handling processing fermentation and waste management. Verma LR and Joshi VK. Indus Publishing Co., New Delhi. 2000;2:1006.

McCann MJ, Gill CIR, O' Brien G, Rao JR, McRoberts WC, Hughes P, McEntee R, Rowland IR. Anti-cancer properties of phenolics from apple waste on colon carcinogenesis in vitro. Food Chemistry and Toxicology.2007; 45:1224-1230.

Mohapatra D, Mishra S, Sutar N. Banana and its by-product utilisation: an overview.Journal of Scientific and Industrial Research.2010;49.

Naz A, Butt MS, Sultan MT, Qayyum MM, Niaz RS. Watermelon lycopene and allied health claims. EXCLI journal. 2014;13:650.

NHB. 2010. National Horticultural Board, Gurgaon, India, www.hortibizindia.org

Pathak P. D, Mandavgane S. A, Kulkarni B. D. Fruit peel waste: Characterization and its potential uses. Current Science.2017;113,1-11.

Pham TP, Kaushik R, Parshetti GK, Mahmood R, Balasubramanian R. Food waste-to-energy conversion technologies. Current status and future directions. Waste Management. 2015 ;38:399-408.

Rahman B. Phytochemical investigation of Citrullus lanatus (Watermelon) rind (Doctoral dissertation, East West University).

Ravani A, Joshi D. Mango and it's by product utilization-a review. Energy (kcal). 2013;74(44):2013.

Ravn-Haren G, Krath BN, Markowski J, Poulsen M, Hansen M, Kołodziejczyk K, Kosmala M, Dragsted LO. Apple pomace improves gut health in Fisher rats independent of seed content. Food \& function. 2018;9(5):2931-41. 
Rehman AB, Gulfraz M, Raja GK, Haq MI, Anwar ZA. Comprehensive approach to utilize an agricultural pea peel (Pisum sativum) waste as a potential source for bio-ethanol production. Romanian Biotechnological Letters. 2015;20(3):10422-30.

Rimando AM, Perkins-Veazie PM. Determination of citrulline in watermelon rind. Journal of Chromatography A. 2005;1078(1-2):196-200.

Romelle FD, Ashwini RP, Manohar RS. Chemical composition of some selected fruit peels. European Journal of Food Science and Technology. 2016;4(4):12-21.

Russ W, Meyer-Pittroff R. Utilizing waste products from the food production and processing industries. Critical reviews in food science and nutrition. 2004;44(1):57-62.

Sagar NA, Pareek S, Sharma S, Yahia EM, Lobo MG. Fruit and vegetable waste: Bioactive compounds, their extraction, and possible utilization. Comprehensive Reviews in Food Science and Food Safety. 2018;17(3):512-31.

Sharma SK, Bansal S, Mangal M, Dixit AK, Gupta RK, Mangal AK. Utilization of food processing by-products as dietary, functional, and novel fiber: A review. Critical reviews in food science and nutrition. 2016;56(10):1647-61.

Simonne A, Carter M, Fellers R, Weese J, Wei C.I, Simonne E. Miller M. Chemical, physical, and sensory characterization of watermelon rind pickles. Journal of Food Processing Preservation.2002:26,415-31.

Skinner RC, Gigliotti JC, Ku KM, Tou JC. A comprehensive analysis of the composition, health benefits, and safety of apple pomace. Nutrition reviews. 2018;76(12):893-909.

Sudha ML, Baskaran V, Leelavathi K. Apple pomace as a source of dietary fiber and polyphenols and its effect on the rheological characteristics and cake making. Food Chemistry. 2007; 104: 686-692.

Sun J, Hu X, Zhao G, Wu J, Wang Z, Chen F, Liao X. Characteristics of thin-layer infrared drying of apple pomace with and without hot air pre-drying. Food Science and Technology International. 2007;13(2):91-7.

Tewari HK, Marwaha SS, Rupal K. Ethanol from banana peels. Agricultural wastes. $1986 ; 16(2): 135-46$.

Udosen EO, Enang MI. Chemical composition and soaping characteristics of peels from plantain (Musa paradisiaca) and banana (Musa sapientum). Global Journal of Pure and Applied Sciences. 2000;6(1):79-82.

Verma, LR. and Joshi VK (Eds), Indus Publishing Co., New Delhi. 2:1006.

Wadhwa M, Bakshi M. P. S, Makkar H. P. Broadening Horizons. Cellulose.2017;80(78.9), 1-35.

Wadhwa M, Kaushal S, Bakshi MP. Nutritive evaluation of vegetable wastes as complete feed for goat bucks. Small Ruminant Research. 2006;64(3):279-84.

Wadhwa M, Bakshi MP, Makkar HP. Wastes to worth: value added products from fruit and vegetable wastes. CAB International. 2015;43:1-25.

Wang C, Lai Q. Advances in comprehensive utilization of fruit peel in China. Academia Journal of Agricultural Research. 2016;4(9):589-92.

Wang S, Chen F, Wu J, Wang Z, Liao X, Hu X. Optimization of pectin extraction assisted by microwave from apple pomace using response surface methodology. Journal of Food Engineering. 2007; 78:693-700.

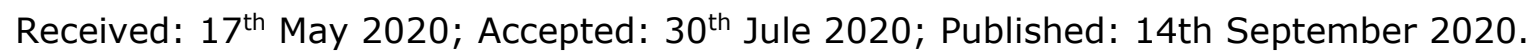


Sustainability, Agri, Food and Environmental Research, (ISSN: 0719-3726), 9(3), 2021: 469-479 http://dx.doi.org/10.7770/safer-VONO-art2213 